\title{
Identification of Worm In Digestive Tract of Consumed Cattle Egret (Bubulcus ibis) In Ujung Pangkah, Gresik
}

\author{
Identifikasi Cacing di Saluran Pencernaan pada Burung Kuntul (Bubulcus ibis) \\ di Ujung Pangkah, Gresik
${ }^{1)}$ Nisa' Rachmaningtyas Putri, ${ }^{2)}$ E. Djoko Poetranto, ${ }^{3)}$ Nunuk Dyah Retno Lastuti, ${ }^{3)}$ Setiawan Koesdarto, ${ }^{2)}$ Bambang Sektiari L, ${ }^{3}$ Kusnoto
${ }^{1)}$ Student, ${ }^{2}$ Clinical Veterinary Department , 3) Parasitology Veterinary Department. Faculty of Veterinary Medicine, Universitas Airlangga

\begin{abstract}
Ujung Pangkah, Gresik was became the most habitat of fowls such as Cattle egret (Bubulcus ibis). The aim of this research were to find out the type of worm that infected digestive tract of Cattle egret (Bubulcus ibis) in Ujung Pangkah, Gresik. The examination of worm in digestive tract was done by dissection and fecal examination. The identification based on morphological of the eggs and worms. The samples of digestive tract organ collected from restaurant that preserve Cattle egret as a main menu. Whereas the fecal sample collected by swab from the intestine. Cattle egret (Bubulcus ibis) has positive infection by worm parasite if there were worm or egg inside the digestive tract. Fecal samples were examined by native, sedimentation, coconut-sugar floating method and EPG counting with Lucient Brumpt. And the worm morphology from dissection of digestive tract would be identify with source book, journal, and discussed with supervisor. The result showed that 20 of digestive tract dissection and 20 fecal samples, there were three types of worm, Contracaecum sp., Cosmocephalus sp., Capillaria sp. and egg of Contracaecum sp. with 200 EPG
\end{abstract}

Keywords : digestive tract,worm, Bubulcus ibis

\section{Introduction}

Indonesia is the richest country in the world in terms of biodiversity. World Resource Institute describe that Indonesia has up to $25 \%$ various species in the world when its land area is only $1.3 \%$ of the total mainland in the world. The length of $81.000 \mathrm{~km}$ coastal line Indonesia has an important role in viability of birds in wetland (Sukara 2008).

Water bird divided into 2 groups, fowl and shorebirds. Shorebird needs small fish, mollusca, crab and worms to eat. Beside of seashore, they also forage in the other wetland like fishpond, swamp, wet rice field, and also mangrove (Howes et al, 2003). Places the shorebird were perched, possible that shorebird infected or infect the fowl because those two confirmed did contact when foraging (Valkiunas, 1991).
Fowl in Indonesia such as Cattle egret (Bubulcus ibis) do not have any specific ecosystem in the process of foraging, they were found all over the world with different weather, niche, ecosystems or environment. Because of the difficulty in searching for their prey, they prefer to follow along side grazing livestock to catch any disturbed lice. Their predilection for thorny and thick trees for nesting was for security purposes, while foraging close by in grassland, farmlands and dry swampy (Fogarty \& Hetrick, 1973).

According to Kusumamiharja (1986) the emergence of a disease can be caused by the types of organisms such as virus, bacterial, fungus, tick, and lice, but most widely spread is worm. Most of the emerging and re-emerging desease was zoonotic disease, means that the disease come from the animals and infect human (WHO, 2014). 
The Cattle egret (Bubulcus ibis) in Ujung Pangkah usually consumed by owner of fishpond and local citizen in Ujung Pangkah itself. Taking benefit of wildlife traditionally has long been done by society, particularly as provider a lot of protein. Cattle egret (Bubulcus ibis) is the types of water birds that have long been used by citizen who live on the coast. On initially the use of the types of birds that only as a protein supply for the local community. (Rusila, Indrawan,1990). Based on background, researcher would like to doing research about identification of worm that could infect digestive tract of Cattle Egret (Bubulcus ibis).

\section{Material and Methods}

Material that use for this research are 20 samples digestive tract of Cattle egret (Bubulcus ibis) in Ujung Pangkah, Gresik. Methods are using dissection of digestive tract and faeces observation with native, sedimentation, and floating method using coconut sugar solution. The data analysis are using field survey with purposive random sampling method because the samples taken from restaurant by the researcher. The result research will be analysis by descriptive analyze and by matching the morphology and length of worm species with "Parasitic Disease of Wild Birds" Ebook by Wiley (2008) and journal "Occurrence of helminth parasites in the gastrointestinal tract of wild birds from Wildlife Rehabilitation and Investigation Centre of Ria Formosa in southern Portugal". by Tomas (2016).

\section{Result and discussion}

Based on this research, have discovered three types of worms in the digestive tract of Cattle egret (Bubulcusibis), such as genus Contracaecum sp., Cosmocephalus sp., andCapillaria sp. (Table 1, figure 1). In Cattle egret (Bubulcus ibis), there are two parts of the digestive tract where the worm found in large quantities, i.e. proventriculus and esophagus (Figure 2), either lumen or mucosa.

Table 1. Nematodes That Found Inside Digestive Tract of Cattle Egret (Bubulcus ibis) and The Measurements

\begin{tabular}{clcc}
\hline No. & Nematodes & Length of Worm & Eggs Found \\
\hline 1 & Contracaecum sp. & $25-30 \mathrm{~mm}$ & Positive, 1 Egg \\
2 & Cosmocephalus sp. & $10-13 \mathrm{~mm}$ & Negative \\
3 & Capillaria sp. & $20-25 \mathrm{~mm}$ & Negative \\
\hline
\end{tabular}

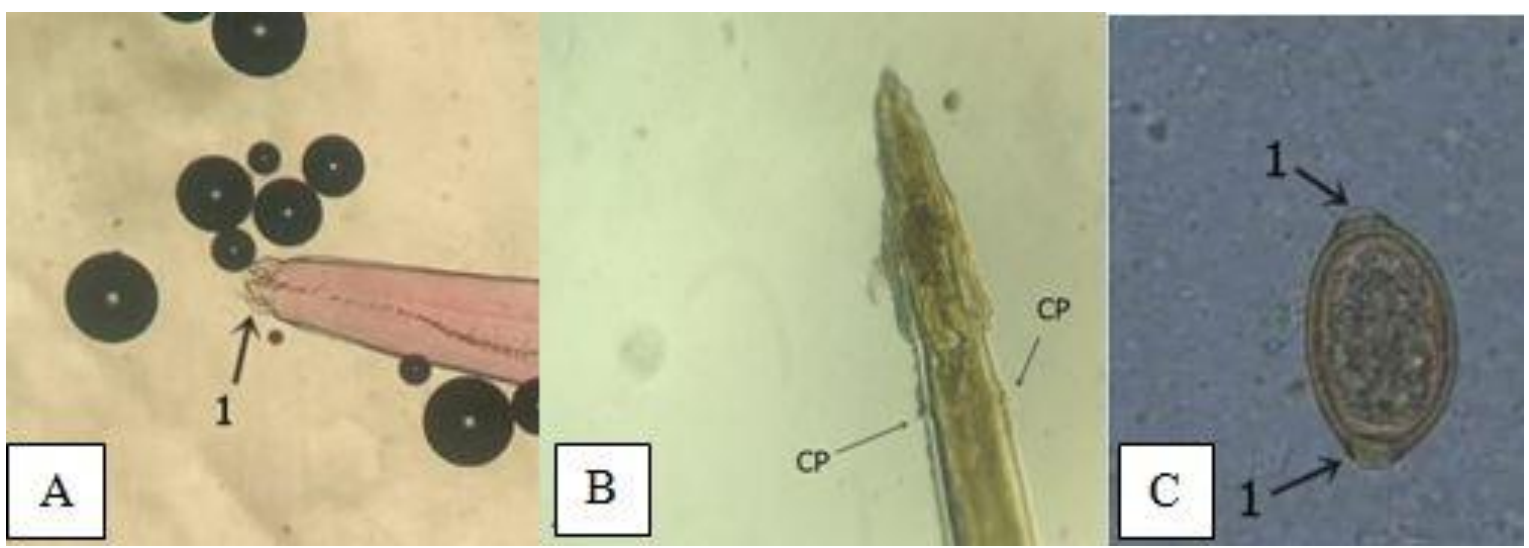

Figure 1. Three Types of Worms in The Digestive Tract of Cattle egret. A = Contracaecum sp., mouth of worm, has 3 big lips (one dorsal and two subventral) with interlabia lips (1), B = Cosmocephalus sp.. anterior, has cervical papillae (CP), $\mathbf{C}=$ Capillaria sp, egg from worm crushing the worm. Operculum present (1), with egg size 6o.04 x $26.14 \mu \mathrm{m}$. 


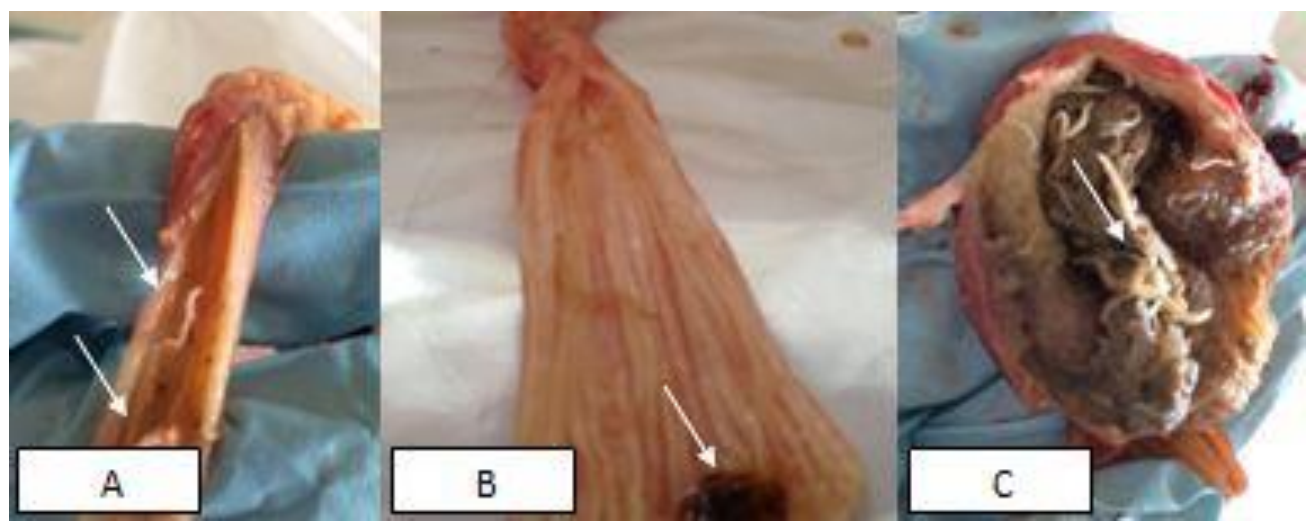

Figure 2. Worms in The Digestive Tract of Cattle egret. A = Esophagus of Cattle egret. worm present (white arrow), $\mathbf{B}=$ Esophagus of Cattle egret. hemorrhagic necrosis by worms (white arrow), $\mathbf{C}=$ Proventriculus of Cattle egret. Contracaecum sp. present (white arrow)

of the 20 samples of digestive tract, 17 digestive tract are positive containing the worm types Contracaecum sp. Identification key by morphology and the length of worm based on the journal "Occurrence of helminth parasites in the gastrointestinal tract of wild birds from Wildife Rehabilitation and Investigation Centre of Ria Formosa in southern Portugal". by Tomas (2016) and identification of egg based on the book "Parasitic Diseases of Wild Birds" by Wiley (2008).

Contracaecum sp. found on both lumen and mucosal of proventriculus and esophagus with a total sample of 125 worms with varying sizes. The worms were found with different amount of each digestive tract, in oesophagus can be infected between 1-24 worms, while in the proventriculus found . between 1-9 worms. Contracaecum sp. in the proventriculus have larger size between 25-30 $\mathrm{mm}$, and Contracaecum sp. that found in esophagus are smaller than in proventriculus, with size ranges $10-20 \mathrm{~mm}$. The smaller size of worms are possible that its Contracaecum sp. which still at L3 stage.

In addition to worms, also found the eggs of Contracaecum sp. in faeces of Cattle egret (Bubulcus ibis) with characteristics of thick-walled oval and have a size of $47.82 \times 57.73 \mu \mathrm{m}$, match with study of Shamsi (2008), which is the size of egg 24-49 x 39-58 $\mu \mathrm{m}$. Contracaecum sp. in addition to having three lips (one dorsal and two subventral) without any teeth and has fully developed interlabia (Thomas et al., 2013). Has a short esophagus, a globular ventriculus and the presence of intestinal cecum. There are up to 7 pairs of post anal papillae on subventral and lateral. Male worms have caudal alae (von Drasche, 1882).

The accumulation number of wormsContracaecum sp. this poses a lot of health problems on bird such as anemia, stress, and peritonitis, but reports of the deaths of wild birds because peritonitis caused by a large accumulation of this worm is low (Deardorff and Overstreet 1980; Greve et al,. 1986).

Infected Cattle egret (Bubulcus ibis) by worms like Contracaecum sp. and Cosmocephalus sp. early found in Portugal based on newest research by Tomas et al., 2016, but In Indonesia no report about infected Cattle egret, especially in Ujung Pangkah where fowl and shorebird were on the same place for foods. The other birds, as Pelican in Autralia also infected by Contracaecum sp. based on journal by Shamsi (2008).

Besides Contracaecum sp., have been foundCosmocephalus sp. found in the mucosa of the esophagus and proventriculus of Cattle egret (Bubulcus ibis) with the general shape having cordon and anastomosing. This is supported by the research of Anderson and Wong (1981), that found Cosmocephalus sp. In the esophageal mucosa. Has a cervical papillae and the male worm has a right and left spicules, in which the left spicule is longer and slender than the right spicule. In accordance with identification keys using research journals of Thomas et al. (2016).

Cosmocephalus worm sp. found in Cattle egret (Bubulcus ibis) amounted only 6 of worms in the digestive tract from overall total sample. The 20 samples, only 3 samples was found posi- 
tive Cosmocephalus sp.The number of worms per sample is only about 1-2 worms only.

According Obiekiezi et al., (1992) the number of Cosmocephalus sp. reported cause granulomas in the abdominal wall of Osmerus eperlanus which became temporary host ofCosmocephalus sp., but the symptoms of worm infection Cosmocephalus sp. in birds still undiscovered (Santoro et al., 2010).

Last genus found in the digestive tract worms of Cattle egret (Bubulcus ibis) is a Capillaria sp. of the 20 samples digestive tract, only 1 sample positive with Capillaria sp. Worm with the characteristics; the length of male Capillaria sp is $\pm 10-48 \mathrm{~mm}$, while the females \pm $10-60 \mathrm{~mm}$, and the size of the eggs is $46-70 \times 24^{-}$ $28 \mu \mathrm{m}$ (Levine, 1990). The infection occurs when the eggs on second stage larvae are ingested by birds, then it will develop into the third and fourth stages that eventually become adult worms (Levine, 1990).

Severe infestation can cause death. Some species Capillaria sp. has a direct life cycle and some have an indirect life cycle. This worm control can be done by controlling the host. Severe infestation of wthis worm cause reduced growth, reduced egg production and reduced fertility. According to Levine (1990), Capillaria sp. in large quantities can be found by dissection the organ, but in this study only 1 sample positive digestive tract that contain Capillaria sp., there are 2 worms Capillaria sp., the eggs are hard to find on bird feces.

Cattle Egret (Bubulcus ibis) could infected with three types of worms through what they ate. Could be seen on the attachment sheet on, the proventriculus of the Cattle Egret (Bubulcus ibis) there are many corpse of small fish and shrimp. Fish and shrimp are the main factors causing bird infections by worms. Contracaecum sp. also has a life cycle that requires fish and shrimp to grow from egg to adult worm.

The Eggs of Contracaecum sp. released by fecal infected birds, will reach the larval stage (L3) in the waters area where there are lots of crustaceans and small fish. Furthermore, the larvae are ingested by fish and encyst to internal organs of fish such as the liver, intestines and other digestive organs. After the fish or shrimp that have been infected are eaten by birds, it will come out from the cyst and began to develop into
L4 larvae in the mucosa of the proventriculus to reach the adult stage. However, there is a possibility that this Contracaecum infect birds with directly life cycle with the adult Contracaecum sp. that ingested by the birds (Huizinga, 1971; Fagerholm, et al., 1996).

Contracaecum sp. is an Anisakidae family worm, which has the possibility to infect other animals or even humans. In the journal, Shamsi (2013) said there have been reports that the worm Contracaecum sp. has ever infect people in the Australian region.

For Cosmocephalus sp. could not be found many sources of the spread of this worm, for its life cycle, Cosmocephalus sp. also need fish to develop into adult worms. Unlike Capillaria sp.which has a directly life cycle.

Those worms can cause some patologic symptoms in the organ of digestive tract, where the worms were developed. In esophagus of Cattle egret where found many worm of Contracaecum sp. occured hemorrhagic necrosis with diameter $\pm 2 \mathrm{~cm}$ caused by obstruction and activity of Contracaecum sp.

Soulsby (1986) describe that the environmental condition of the pile of stools is the development of worm larvae into larvae. In addition to being influenced by season and environment, the spread of parasitic diseases in infecting host can be through feed, drink, or infected ground eggs containing infective larvae (Hendarni, 2015). Levine (1990) states one important factor in the occurrence of parasitic worm infections is the animal's immune system and there are several factors that can suppress the immune system against the parasite and support the predisposition of parasitic infections in the host is the density of animal groups, poor sanitation, contaminated soil and contact with wild bird species.

EPG calculation The results by using Lucient Brumpt did not show any major infection in faeces of Cattle egret (Bubulcus ibis) which is considered low because only identified o-200 EPG. EPG results can not show severe degree of infection in Cattle egret (Bubulcus ibis) because in this research, there is a result that not whole samples of digestive tract that thas many worms also contained worm eggs in the faeces. 


\section{Conclusions}

Identified species inside digestive tract of Cattle egret (Bubulcus ibis) are in 3 genus, consist; Contracaecum sp. that found in the proventriculus and esophagus, Cosmocephalus sp. that found in the proventriculus, and Capillaria sp. in proventriculus.The calculation results of EPG shows the intensity of infection of eggs in the faeces of Cattle egret (Bubulcus ibis) in Ujung Pangkah are 200 EPG.

\section{References}

Andiarsa, D., B. Hariani, G. Meliyanie and D. Fakhrizal. 2012. Infeksi Cacing, Imunitas, dan Alergi. Jurnal Epidemiologi dan Penyakit Bersumber Binatang. 4: 47-52

Anderson R.C and P.L. Wong. 1981. Redescription of Cosmocephalus obvelatus (Creplin, 1982) Nematoda : Acuarioidea from Larus delawarensis Ord (Laridae). Department of zoology, College of Biological Science, University of Guelph, Ont., Canada.

Brown, L.H., E.K. Urban, and K. Newman, 1982. The Birds of Africa, Volume I. Academic Press, London.

Birds of New Zealand. 2005. Cattle egret. New Zealand Birds Limited: Greytown, New Zealand. http://www.nzbirds.com/birds/catt leegret.html. Access on 15 Jun. 17.

Deardorff, T.L. and R.M. Overstreet. 1980. Contracaecum multipapillatum ( 5 C. Robustum) from fishes and birds in the northern. Gulf of Mexico. Journal of Parasitology 66: 853856.

Del Hoyo, j.A. Elliot, and J. Sargatal, 1992. Handbook of the Birds of the World, vol. 1: Ostrich to Ducks. Lynx Edicions, Barcelona, Spain.

Elfidasari, 2005. Pengaruh Perbedaan Lokasi Mencari Makan Terhadap Keragaman Mangsa Tiga Jenis Kuntul Di Cagar Alam Pulau Dua Serang: Casmerodius albus, Egretta garzetta, Bubulcus ibis

Environmental Systems Research Institute. 2015. Ujung Pangkah Paperline Network. Saka Indonesia Pangkah Limited.
Ernawati, Y dan Muhammad I, I, 2011. Gonad Maturity of Herrings (Clupea platygaster) in Ujung Pangkah Waters, Gresik, East Java

Fagerholm H-P, R.M. Overstreet and I. Humphery-Smith 1996 Contracaecum magnipapi-llatum (Nematoda, Ascaridoidea): resurrec-tion and pathogenic effect of a common parasite from the proventriculus of Anous minutus from the Great Barrier Reef, with a note on $C$. variegatum. Helminthologia; 33

Fogarty, M.J. and W.M. Hetrick, 1973. Summer Foods of Cattle Egrets in North Central Florida. AUK, 90: 268-80

Greve J.H, HF Albers, B Suto and J Grimes. Pathology of gastrointestinal helminths in the brown pelican (Pelecanus occidentialis). Avian Dis 1 986; 30: 482-7

Hancock, J. 1982. Aerial Stretch Display of the Eastern Race of the Great White Egret (Egretta alba). Ibis 126: 92-

Hancock, J. and J. Kushlan, 1984. The Herons Handbook. Croom Helm, London.

Hove, J, and M.E. Scott, , 1988, Ecological studies on Cyathocotyle bushiensis (Digenea) and Sphaeridiotrema globulus (Digenea), possible pathogens of dabbling ducks in southern Quebec: Journal of Wildlife Diseases, v. 24, p. 407-421.

Howes, J. D., , Y. R. Noor. Bakewell.2003. Panduan Studi Burung Pantai. Buku.

Huizinga HW. Contracaeciasis in Pelicaniform.Birds. J Wild! Dis 1971 ; 7: 198-204

Hungerford, T. G. 1970. Disease of Live Stock. $7^{\text {th }}$ Resived Ed. Angus and Robertson. Sidney. London. Melbourne. Singapore. 325-328.

IUCN Red List of Threatened Species. 2016 .Bird Life International.. Bubulcusibis..2016:e.T22697109A8645405o.http://dx.doi.org/10.2305/ IUCN.UK.2016 3.RLTS.T22697109A8645050.

Kosasih, A., 1982. The Audubon Society Handbook For Birders, New York.

K, R, J Brabec, P,K, ckova , T Scholz. 2013. Tapeworm Diphyllobothrium dendriticum (Cestoda) Neglected or Emerging Human 
Parasite. Institute of Parasitology, Biology Centre of the Academy of Sciences of the Czech Republic, Ceske Bude`jovice, Czech Republic, University Hospital Brno, Brno, Czech Republic.

Kusnoto, S. Subekti, S. Koesdarto, and S. M. Sosiawati. 2014. Buku Ajar Helmintologi Kedokteran Hewan. Edisi 1. Zifatama Publisher. Sidoarjo

Kusumamiharja, S. 1986. Pengendalian dan Pemberantasaan Penyakit Cacing Poultry Indonesia. Edisi Juli No. 75. 25-26.

Levine, N. D. 199o. Parasitologi Veteriner. Gadjah Mada University Press. Yogyakarta. 113-293.

Mumpuni, S., S. Subekti, S. Koesdarto, H. Puspitawati dan Kusnoto. 2007. Penuntun Praktikum Ilmu Penyakit Helmint Veteriner. Fakultas Kedokteran Hewan Universitas Airlangga. Surabaya.

Olsen, W. 1962. Animal parasites: their biology and life cycles. Burgess Pub. Co., Minneapolis, Minn., 346 p.

Poetranto, E. D. 1992. Efektivitas berbagai larutan Pengapung terhadap penemuan telur strongyl pada tinja sapi [M.S. Thesis]. Fakultas Kedokteran Hewan. Universitas Gadjah Mada

Poetranto, E.D. 2013. Fishponds in Ujung Pangkah. Photographed in Ujung Pangkah, Gresik.

Rusila-Noor, Y., M. Khazali, and I.N.N Suryadiputra. 1999. Panduan Pengenalan Mangrove di Indonesia. PKA \& Wetlands International-Indonesia Programme. Bogo

Sazima, I. \& Sazima, C. 2010. Brazilian Cleaner Birds: Update and Rreappraisal. Universidade Estadual de Campinas - UNICAMP. Brazil

Scholz, T., Kuchta R.2016. Fish-Borne, Zoonotic Cestodes (Diphyllobothrium And Relatives) In Cold Climates: A Never-Ending Story Of Neglected And (Re)-Emergent Parasites. Institute Of Parasitology, Biology Centre, Czech Academy Of Sciences, Branišovská
Shamsi, Shokoofe and Robin B Gasser, Ian Beveridge \& Afshin Alizadeh Shabani. 2013. Contracaecum pyripapillatum n. sp. (Nematoda: Anisakidae) and a description of C. multipapillatum (von Drasche, 1882) from the Australian pelican, Pelecanus conspicillatus. University of Melbourne. Australia.

Soulsby, E.J.L. 1986. Helminths, Anthropods and Protozoa of Domesticated Animals-7th edition. The English Language Book Society and Bailliere, Tindall. London. $767-773$.

Subronto and I. Tjahajati. 2011. Ilmu Penyakit Ternak II. Gadjah Mada University Press. Yogyakarta

Sri Subekti, Sri Mumpuni, S. Koesdarto, H. Puspitawati dan Kusnoto.2005. Buku Ajar Helmintologi Veteriner. Universitas Airlangga Surabaya

Sukara, E., I. SL. Tobing. 2008. Industri Berbasis Keanekaragaman Hayati, Masa Depan Indonesia. Vis Vitalis. 1: 1-12.

Timm, Claudio Dias. 2009. Cattle Egret in Breeding Plumage. Photographed in Rio Grande do sul. Brazil

Tomas Andre, Maria Teresa R, Isabel P.2016. Occurance of helminth parasites in the gastrointestinal tract of wild birds from Wildlife Rehabilitation and Investigation Centre of Ria Formosa in Southern Portugal. Veterinary Parasitology : Regional Studies and Reports. Lisbon. Portugal

Urquhart GM, Armour J, Duncan AM, Jennings FW. 1996. Veterinary Parasitology, 2nd ed. Blackwell Science, Scotland, pp: 39-58.

Valkiunas, G.,1991. The Role Of Seasonal Migrations In The Distribution Of Haemosporidia Of Birds In Noth Palearctic. Ekologija 1993, 57 \pm 73 . 